\title{
Use of waste mushroom beds for the production of value-added biodegradable fiber sheet
}

\author{
Walaiporn Suksai ${ }^{1}$, Chaniga Chuensangjun ${ }^{2, *}$, Jittimon Wongsa ${ }^{3}$, Vilai Rungsardthong ${ }^{1}$, Savitri Vatanyoopaisarn ${ }^{1}$, \\ Benjawan Thumthanaruk ${ }^{1}$, Rungsima Yeetsorn ${ }^{4}$, and Buddhi P. Lamsal ${ }^{5}$
}

${ }^{1}$ Department of Agro-Industrial, Food and Environmental Technology, Faculty of Applied Science, Food and Agro-Industry Research Center, King Mongkut's University of Technology North Bangkok, Bangkok 10800, Thailand.

${ }^{2}$ Science and Technology Research Institute, King Mongkut's University of Technology North Bangkok, Bangkok 10800, Thailand.

${ }^{3}$ Department of Agricultural Engineering for Industry, Faculty of Industrial Technology and Management, King Mongkut's University of Technology North Bangkok, Prachinburi 25230, Thailand.

${ }^{4}$ The Sirindhorn International Thai-German Graduate School of Engineering, King Mongkut's University of Technology North Bangkok, Bangkok 10800, Thailand.

${ }^{5}$ Department of Food Science and Human Nutrition, Iowa State University, 536 Farm House Lane, Ames, IA 50011-1054, USA.

\begin{abstract}
This research focused on the utilization of waste mushroom beds (WMB) after the harvesting of oyster (WMB-O) and lingzhi mushrooms (WMB-L) for the preparation of eco-friendly materials, fiber sheets. The WMB were sterilized and determined for their chemical compositions. The dry fiber of the sterilized WMB were pretreated by a steam explosion, comparing with alkaline pretreatment before the fiber sheet forming process. The results showed that $\alpha$-cellulose contents of the WMB were in the range of $27-35 \%$ by dry weight basis. The fiber from WMB-L treated by alkaline at $13.5 \% \mathrm{w} / \mathrm{w}$ of $\mathrm{NaOH}$ for 120 min showed better fiber sheet appearance, compared to the steam explosion. Afterward, tapioca starch was added as a natural binder during the fiber sheet forming and their physical properties were determined. The analytical results indicated that an increase of $\mathrm{NaOH}$ concentration in the pretreatment led to an increase in the toughness and water absorption of the fiber sheet. The additional tapioca starch promoted the interaction between cellulose fiber networks, corresponding to the decrease of water absorption and a compressed appearance after water immersion. These finding results disclosed a potential use of the WMB as ecofriendly materials, e.g. biodegradable packaging, packing materials, cultivation vase in the future.
\end{abstract}

Keyword. Bio-material, Eco-friendly material, Lingzhi mushroom, Oyster mushroom, Pretreatment, Waste mushroom bed

\section{Introduction}

Mushroom are popularly consumed in many countries because of their texture, aroma, taste as well as their high nutritional composition. Mushrooms indicate high fiber content, low energy, high nutrition, and low calories. Several varieties of mushrooms contain bioactive compounds and present medicinal properties and health benefits. Generally, mushrooms are grown on timber rotting decay, manure, or compost. Some species need specific nutrients for their growth. Moreover, most species of mushrooms require high humidity up to 70$90 \%$, especially during their caps opening. Water holding capacity of planting containers and humidity control are important factors for mushroom cultivation $[1,2]$. Nowadays, mushroom farmings are widely expanded. There are three types of mushroom cultivations in Thailand including the cultivation in the wooden pickup, in the plastic bag, and on timber. The plastic bags for mushroom cultivation are commonly used because they have heat resistance, require a small cultivation area with convenient preparation and easy removability [2]. Lignocellulosic materials such as rice bran and sawdust are generally used as raw materials for mushroom cultivation in the plastic bag because they are abundant agricultural waste resources and degradable under the natural environment [3]. After the first mushroom cultivation, the nutrients in the culture medium were reduced and some types of mushroom beds could be reused with the addition of necessary nutrients, while some species of edible mushroom bed could be reused up to 5 times [4]. The mushroom beds after cultivation still contain some components or nutrition needed for another cultivation, especially fiber cellulose, hemicellulose, and lignin [5]. The waste mushroom beds (WMB) could be utilized as raw materials for the production of reducing sugars for biodiesel production [6], planting crops [7], and hydrogen production for the growth of Clostridium thermocellum [8]. According to the information obtained from the Thai Intellectual Learning Center Samutprakarn (Samutprakarn Province, Thailand), one of the large mushroom farms in Thailand, the oyster and lingzhi mushrooms are the two most popularly cultivated as edible, and medicinal mushrooms in the market, respectively. Generally, after-harvesting in mushroom

* Corresponding authors: chaniga.c@stri.kmutnb.ac.th 
cultivation, the WMB are discarded rather than reused due to the insufficient nutrients for cultivation to the growth of the mushrooms. Consequently, there are a lot of WMB and the discarded plastic bags in many mushroom farms presently. The wastes are underuse and require waste management or utilization into more valuable products. Substitution of plastic planting containers using degradable materials is one expected alternative to reduce the waste plastics in mushroom farms.

Cellulose fibers from the lignocellulosic material and agricultural wastes, such as mulberry inner bark, rubberwood sawdust, spent coffee grounds, straw, etc. are reported for the preparation of high value-added ecofriendly materials, such as natural paper, the substrate for biorefining process, natural fiber-reinforced composites or degradable cultivation vase [9-12]. Eco-friendly fiber sheets prepared from cellulose fibers or agricultural wastes were reported, such as the use of Phyllostachys (bamboo) to produce carbonaceous fiber sheets for preparing the gas diffusion layers of proton exchange membrane fuel cells [13] and production of the biocomposite films from cassava starch by using cellulose extracted from durian rind as reinforcement agent [14]. However, there were no the published reports about the preparation of fiber sheets from WMB. Therefore, the preparation of water-absorbent and biodegradable fiber sheets from WMB would be interesting for further application in the future. The high water holding capacity and biodegradability of obtained fiber sheets are expected for forming the mushroom cultivation vase, lead to reduced frequency for watering, and promote zero waste in the mushroom farms.

Cellulose $\left(\mathrm{C}_{6} \mathrm{H}_{10} \mathrm{O}_{5}\right)$ is a polysaccharide that contains D-glucose linked together by B-1,4-glycosidic bonds [15-16]. Each chain of cellulose is interacted by hydrogen bonds, resulting in high strength structure of the cellulose network [17]. Natural cellulose can be extracted from the plant (wood and non-wood), animal, and some microorganisms [15], therefore, cellulose is the most abundant lignocellulosic materials in the world [18]. Moreover, there are many reports on the properties of natural cellulose fiber including its advantages, potential use for renewable resources, strong and tough structure, and water absorbability [19-21]. Cellulose has been used in several industries including food, pharmaceutical, and textile industries [22]. However, the pretreatment of raw materials is an important process to remove lignin, hemicellulose, and other extractives from the raw materials to obtain high purity of cellulose [23]. For the preparation of fiber sheets from agricultural waste, high cellulose fiber contents and remained fibrous morphology are main characteristics of the pretreated raw materials [13], especially for the production of fiber sheets with high water absorption. Alkaline pretreatment and steam explosion could break the strong interaction between hemicellulose, lignin, and cellulose, resulting in an increase of porous structure in the cellulose fiber [24].

In this study, the potential use of WMB from oyster (WMB-O) and lingzhi mushrooms (WMB-L) cultivation as fiber sheets, the biodegradable material was investigated. Both fibers were pretreated by a steam explosion and compared to the alkaline treatment. The fiber sheets were formed and their physical properties such as toughness, water absorption, swelling, and porosity were measured according to the Thai Industrial Standard (876-2547) [10,25] to evaluate their potentials for further applications in the future.

\section{Materials and methods}

\subsection{Materials}

Both WMB after harvesting for 7 days, WMB-O from oyster (Pleurotus ostreatus) and WMB-L from lingzhi (Ganoderma lingzhi) cultivation (Fig. 1.) were supplied from Thai Intellectual Learning Center (Samutprakarn Province, Thailand).
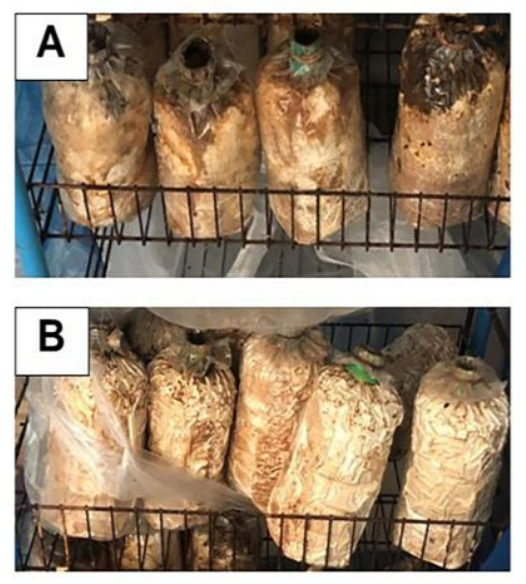

Fig. 1. Waste oyster (A) and lingzhi (B) mushroom beds after harvesting for 7 days.

Tapioca starch to be used as a natural binder for preparing the fiber sheet was derived from Tongchan Co., Ltd. (Bangkok, Thailand). Sodium hydroxide $(\mathrm{NaOH})$ to be used for the alkali pretreatment was the commercial-grade product obtained from Chemiall Co., Ltd. (Bangkok, Thailand).

\subsection{Methods}

\subsubsection{Preparation of natural fibers from WMB-O and $W M B-L$}

The sterilization of WMB-O and WMB-L was carried out in an autoclave at $121^{\circ} \mathrm{C}$ for $1.5 \mathrm{~h}$. Thereafter, the sterile WMB-O and WMB-L were dried in a hot air oven at $60^{\circ} \mathrm{C}$ for $24 \mathrm{~h}$. The dried WMB samples were ground and kept in closed plastic bags at room temperature until the composition analysis and preparation of the fiber sheets.

\subsubsection{Chemical composition analysis}

The chemical composition analysis including moisture content, ash, solvent extractives, lignin, holocellulose 
(alpha-cellulose and hemicellulose) of the dried WMB were determined according to the Technical Association of the Pulp and Paper Industry (TAPPI) [26], as followed.

\subsubsection{Moisture content}

Moisture cans were weighed, then $1 \mathrm{~g}$ of the WMB-O and WMB-L sample was added into each moisture can. The samples were dried in a hot air oven at $105^{\circ} \mathrm{C}$ for $24 \mathrm{~h}$ after they were cooled down in a desiccator. The moisture content $(\%)$ of the samples was calculated according to equation (1).

$$
\text { Moisture content }(\%)=[(\mathrm{A}-\mathrm{B}) / \mathrm{A}] \times 100
$$

when $\mathrm{A}$ is the weight of the sample before drying $(\mathrm{g})$ and $\mathrm{B}$ is the weight of the sample after drying $(\mathrm{g})$.

\subsubsection{Ash}

A crucible was burnt at $550^{\circ} \mathrm{C}$ for $15 \mathrm{~min}$, cooled down in the desiccator, and weighed. A $1 \mathrm{~g}$ (dry matter basis) of the WMB-O, and WMB-L was added into the crucible. The samples were burnt at $550^{\circ} \mathrm{C}$ until the white ashes were obtained. The samples were cooled down and weighed. The ash content of the samples was calculated according to equation (2).

$$
\operatorname{Ash}(\%)=(\mathrm{A} / \mathrm{B}) \times 100
$$

when $\mathrm{A}$ is the weight of ash $(\mathrm{g})$ and $\mathrm{B}$ is the weight of the sample (g).

\subsubsection{Solvent extractives}

Extractives which are the plant resin, wax, alkaloid, and flavonoid that could be dissolved in an organic solvent were extracted from both WMB-O and WMB-L (3 g dry matter basis) using a soxhlet extractor for $4 \mathrm{~h}$. A mixture of ethanol and benzene (1:2) was used as solvents for the extraction. The solvents were then vaporized from the extracted samples overnight followed by the drying at $105^{\circ} \mathrm{C}$ in a hot air oven and cooled down in a desiccator before their weight measurement. The solvent extractives were calculated according to equation (3).

$$
\text { Solvent extractives }(\%)=[(\mathrm{A}-\mathrm{B}) / \mathrm{C}] \times 100
$$

when $\mathrm{A}$ is weight of extracted sample $(\mathrm{g}), \mathrm{B}$ is weight of blank (solvent) $(\mathrm{g})$ and $\mathrm{C}$ is weight of the WMB $(\mathrm{g})$.

\subsubsection{Lignin}

The extracted samples $(3 \mathrm{~g})$ were secondly extracted for $4 \mathrm{~h}$ using $200 \mathrm{~mL}$ of the $95 \%$ ethanol. Samples were left in a fume hood at room temperature overnight and then filtered with a Buchner funnel. The precipitates were washed several times with distilled water and left in the fume hood at room temperature $\left(25 \pm 2^{\circ} \mathrm{C}\right)$ for $2 \mathrm{~h}$ before drying in a hot air oven at $60^{\circ} \mathrm{C}$ for $24 \mathrm{~h}$. The extractivefree samples of $0.35 \mathrm{~g}$ were added to the beaker in an ice bath. The concentrated $\mathrm{H}_{2} \mathrm{SO}_{4}(72 \%$ w/w) of $5.21 \mathrm{~mL}$ was gently added into the beaker. The mixture was stirred every $15 \mathrm{~min}$ for $2 \mathrm{~h}$, at room temperature. Subsequently, the sample was added into the distilled water of $139.13 \mathrm{~mL}$, and the total volume was adjusted to $200 \mathrm{~mL}$ by distilled water. Sample solutions were condensed for $4 \mathrm{~h}$ by a reflux technique, after that the solutions were poured into a beaker and left for $16 \mathrm{~h}$ at room temperature. The sample was filtered and dried at $105^{\circ} \mathrm{C}$ for $3 \mathrm{~h}$. The beaker containing the sample was cooled down in the desiccator and weighed. The lignin was calculated according to equation (4).

$$
\operatorname{Lignin}(\%)=(\mathrm{A} / \mathrm{B}) \times 100
$$

when $A$ is the weight of lignin $(\mathrm{g})$ and $\mathrm{B}$ is the weight of the sample $(\mathrm{g})$.

\subsubsection{Holocellulose}

The extractive-free samples of $3 \mathrm{~g}$ were suspended in a mixture of water $(350 \mathrm{~mL})$, acetic acid $(1.1 \mathrm{~mL})$, and $\mathrm{NaCl}$ (3.3 g). The sample suspension was incubated in a water bath shaking at $70^{\circ} \mathrm{C}$ for $3 \mathrm{~h}$. The acetic acid of 1.1 $\mathrm{mL}$ and $\mathrm{NaCl}$ of $3.3 \mathrm{~g}$ were added into the suspension every hour ( 3 times). At the end of the reaction, the suspension was cooled down to $10^{\circ} \mathrm{C}$ in the ice bath before the filtration. The precipitates were dried at $105^{\circ} \mathrm{C}$ for $16 \mathrm{~h}$ and then cooled down in a desiccator before the weight measurement. The holocellulose was calculated according to equation (5).

$$
\text { Holocellulose }(\%)=(\mathrm{A} / \mathrm{B}) \times 100
$$

when A is the weight of holocellulose ( $\mathrm{g}$ ) and B is the weight of the sample $(\mathrm{g})$.

\subsubsection{Alpha-cellulose and hemicellulose}

The holocellulose of $1.5 \mathrm{~g}$ was mixed with $75 \mathrm{~mL}$ of $\mathrm{NaOH}(17.5 \% \mathrm{w} / \mathrm{v})$. The mixture was cooled down to $2.5 \pm 0.2^{\circ} \mathrm{C}$ in the ice bath and stirred with a magnetic bar for $30 \mathrm{~min}$. The magnetic bar was washed with 2.5 $\mathrm{mL}$ of $\mathrm{NaOH}(17.5 \% \mathrm{w} / \mathrm{v})$ and then adjusted the total volume of the mixture to $100 \mathrm{~mL}$ by distilled water. The mixture was continuously stirred for $30 \mathrm{~min}$ at $2.5 \pm$ $0.2^{\circ} \mathrm{C}$. The sample mixture was filtered and washed with distilled water until the neutral $\mathrm{pH}$ was obtained. The acetic acid $(10 \% \mathrm{v} / \mathrm{v})$ of $40 \mathrm{~mL}$ was then added to the sample precipitates and filtered. The precipitates were dried at $105^{\circ} \mathrm{C}$ for $16 \mathrm{~h}$ and cooled down in the desiccator before being weighed. The alpha-cellulose was calculated according to equation (6).

$$
\text { Alpha-cellulose }(\%)=(\mathrm{A} / \mathrm{B}) \times 100
$$

when A is the weight of alpha-cellulose $(\mathrm{g})$ and $\mathrm{B}$ is the weight of the holocellulose $(\mathrm{g})$.

Hemicellulose was calculated according to equation (7).

$$
\text { Hemicellulose }(\%)=\mathrm{A}-\mathrm{B}
$$


when $\mathrm{A}$ is the percentage of holocellulose and $\mathrm{B}$ is the percentage of the alpha-cellulose.

\subsubsection{Optimization of the fiber pretreatment}

The optimal conditions for an alkaline pretreatment of the WMB fibers were investigated using the sterilized WMB-O and WMB-L fibers as the raw materials. The concentration of $\mathrm{NaOH}$ was studied at 1.5, 5.5, 9.5, and $13.5 \% \mathrm{w} / \mathrm{w}$ ( $\mathrm{g} \mathrm{NaOH} / \mathrm{g}$ dry fiber) in this study. The fibers (30 $\mathrm{g}$ dry basis) were boiled in the $\mathrm{NaOH}$ solution for variable times, namely 5, 60, 90, and $120 \mathrm{~min}$. In addition, a steam explosion technique was used to compare with the alkaline pretreatment. Briefly, the fibers (30 $\mathrm{g}$ dry basis) were steamed in an autoclave at $121^{\circ} \mathrm{C}$ for $5,60,90$, and $120 \mathrm{~min}$. The pretreated fibers from both methods were used for the preparation of the natural fiber sheet.

\subsubsection{Preparation of fiber sheet}

The pretreated pulps from WMB-O and WMB-L were soaked in water (1 g dry basis:30 mL) overnight, and then the pulp suspension was agitated homogeneously. The binder, tapioca starch was dissolved in water to obtain $10 \% \mathrm{w} / \mathrm{v}$. The pulp was mixed with the tapioca starch solution at the weight ratio of $60: 40$ [10]. The mixture was thoroughly spread on a mold $(21.59 \mathrm{~cm} \times$ $27.94 \mathrm{~cm}$ ), and the natural fiber sheet was then dried under the sunlight for 1 day. Thereafter the fiber sheets obtained from each WMB were peeled carefully from the mold. The significant properties of the fiber sheet, such as water absorption and swelling, were measured with the standard method of Thai Industrial Standards Institute (876-2547) [25]. The mulberry paper and printing paper (80 grammages) with the same thickness were used for the comparison of their properties.

\subsubsection{Characterization of fiber sheet}

\subsubsection{Toughness}

The fiber sheet was cut into pieces $(50 \times 50 \mathrm{~mm})$. The top side of the fiber sheet was held on a shoulder pole whereas the bottom side of the fiber sheet was bound vertically to a plastic bag. The sand was slowly added into the plastic bag until the fiber sheet started to tear. The toughness of the fiber sheet was measured as the weight of the sand was put in the plastic bag. All measured data were given as mean values standard deviation (SD) of triplicate measurements.

\subsubsection{Water absorption and swelling}

The three pieces of fiber sheet $(50 \times 50 \mathrm{~mm})$ were weighed and immersed in $120 \mathrm{~mL}$ of water and kept at room temperature. The fiber sheet piece was removed from the water every $30 \mathrm{~min}$, dabbed with absorbent tissue paper to remove the surface moisture, and weighed until a constant weight was observed. The absorption was calculated according to equation (8).

$$
\text { Absorption }(\mathrm{g} / \mathrm{g})=\left(\mathrm{W}_{\mathrm{a}}-\mathrm{W}_{\mathrm{b}}\right) / \mathrm{W}_{\mathrm{b}}
$$

when $\mathrm{W}_{\mathrm{a}}$ is the weight of the fiber sheet after immersion (g) and $\mathrm{W}_{\mathrm{b}}$ is the weight of the fiber sheet before immersion (g) [27]. For the determination of swelling, the thickness of the fiber sheet $(50 \times 50 \mathrm{~mm})$ was measured using a hand-held manual micrometer to prevent compression, after that the fiber sheet was immersed in water for $180 \mathrm{~min}$ at room temperature. The fiber sheet piece was removed from the water, determined for its thickness and swelling ability according to equation (9)

$$
\text { Swelling }(\%)=\left[\left(\mathrm{T}_{\mathrm{a}}-\mathrm{T}_{\mathrm{b}}\right) / \mathrm{T}_{\mathrm{b}}\right] \times 100
$$

when $T_{a}$ is the thickness of the fiber sheet after immersion $(\mathrm{cm})$ and $\mathrm{T}_{\mathrm{b}}$ is the thickness of the fiber sheet before immersion $(\mathrm{cm})[28]$.

\subsubsection{Porosity}

The volume of the fiber sheet $\left(\mathrm{V}_{\mathrm{s}}\right)$ was measured using a micrometer and its density $\left(\rho_{\mathrm{b}}\right)$ was calculated according to [28]. The fiber sheet was ground, added into a volumetric flask $(250 \mathrm{~mL})$, and weighed. Then $120 \mathrm{~mL}$ of water was added into a volumetric flask and the suspension of the sample was mixed thoroughly. The sample was incubated in a water bath at $80^{\circ} \mathrm{C}$ until the steam was observed and then the sample was cooled down in an ice bath. Water was added into the volumetric flask to adjust the volume, and the flask was weighed again [25]. The porosity $(\varepsilon)$ was calculated according to equation (10)-(13), respectively.

$$
\begin{gathered}
\mathrm{V}_{\mathrm{w}}=\left(\mathrm{m}_{2}-\mathrm{m}_{1}\right) / \rho_{\mathrm{w}} \\
\mathrm{V}_{\mathrm{s}}=\mathrm{V}_{\mathrm{F}}-\mathrm{V}_{\mathrm{w}} \\
\rho_{\mathrm{s}}=\mathrm{m}_{\mathrm{s}} / \mathrm{V}_{\mathrm{s}} \\
\varepsilon=\left[1-\left(\rho_{\mathrm{b}} / \rho_{\mathrm{s}}\right)\right] \times 100
\end{gathered}
$$

when $\mathrm{m}_{1}$ is weight of the volumetric flask contained sample $(\mathrm{g}) ; \mathrm{m}_{2}$ is weight of the volumetric flask contained suspension after incubation $(\mathrm{g}) ; \mathrm{m}_{\mathrm{s}}$ is mass of sample $(\mathrm{g}) ; \mathrm{V}_{\mathrm{w}}, \mathrm{V}_{\mathrm{s}}, \mathrm{V}_{\mathrm{F}}$ are volume of water suspension, sample and volumetric flask $(\mathrm{mL}) ; \rho_{\mathrm{w}}, \rho_{\mathrm{s}}, \rho_{\mathrm{b}}$ are density of water $\left(\right.$ at $\left.80^{\circ} \mathrm{C}\right)$, sample and fiber sheet $\left(\mathrm{g} / \mathrm{cm}^{3}\right)$, respectively.

\section{Results and discussion}

\subsection{Chemical compositions}

The chemical compositions of WMB-O and WMB-L i.e. ash, extractives, lignin, holocellulose, alpha-cellulose, and hemicellulose, are presented in Table 1. The chemical compositions of WMB-O were significantly different from those of WMB-L, except extractives, as 
shown in Table 1. The WMB-L contained a lower amount of ash, extractives, and lignin than the WMB-O. This implied that the WMB-L comprises fewer residue nutrients, compared to the WMB-O. According to the information from the mushroom farm (Thai Intellectual Learning Center, Samutprakarn Province, Thailand), the oyster mushroom bed could be reused as many times up to 5 times while the lingzhi mushroom bed is a disposable bed due to some insufficient substances for re-cultivation. In terms of holocellulose which is comprised of alpha-cellulose and hemicellulose, the WMB-O showed a higher amount of alpha-cellulose, but contained a lower amount of hemicellulose compared to the WMB-L. However, this result might due to the growth of bacteria and fungi in the lingzhi mushroom beds which could produce a cellulosic enzyme to degrade the cellulose [29]. In addition, the xylanase and laccase enzyme activity were also found in the oyster mushroom bed [30], resulting in possible degradation of hemicellulose and lignin in the mushroom beds too [31].

Table 1. Chemical compositions of waste mushroom beds.

\begin{tabular}{|c|c|c|}
\hline $\begin{array}{c}\text { Chemical } \\
\text { compositions }\end{array}$ & $\begin{array}{c}\text { Waste oyster } \\
\text { mushroom bed } \\
\text { (WMB-O) } \\
\text { (\% dry basis) }\end{array}$ & $\begin{array}{c}\text { Waste lingzhi } \\
\text { mushroom bed } \\
\text { (WMB-L) } \\
\text { (\% dry basis) }\end{array}$ \\
\hline Exh & $16.01 \pm 2.43^{\mathrm{a}}$ & $9.38 \pm 0.74^{\mathrm{b}}$ \\
\hline Lignin & $15.13 \pm 0.64^{\mathrm{a}}$ & $7.29 \pm 0.87^{\mathrm{b}}$ \\
\hline Holocellulose & $42.44 \pm 0.69^{\mathrm{a}}$ & $46.36 \pm 1.42^{\mathrm{b}}$ \\
\hline$\alpha^{\mathrm{a}}$-Cellulose & $34.82 \pm 1.85^{\mathrm{a}}$ & $27.33 \pm 2.30^{\mathrm{b}}$ \\
\hline Hemicellulose & $7.61 \pm 1.43^{\mathrm{a}}$ & $19.03 \pm 2.3^{\mathrm{b}}$ \\
\hline
\end{tabular}

Values within the same row followed by the same letter are not significantly different $(\mathrm{p}>0.05)$

ns: not significantly different $(p>0.05)$

\subsection{Optimization of the fiber pretreatment}

Fiber pretreatment aimed to remove undesirable elements such as lignin, hemicellulose, and extractives from the WMB before the forming process for the fiber sheet. Comparison of the methods for WMB pretreatment (steam explosion and alkaline solution) and type of WMB (WMB-O and WMB-L), demonstrated a different appearance of the pretreated fiber sheets as presented in Fig. 2. The pretreated fiber from the WMB-O showed a very rough surface, dark color, brittle, and unable to prepare as the fiber sheets by both pretreatment methods. This might be due to residual lignin after the pretreatment [32]. The results of steam explosion pretreatment of WMB-L at $121^{\circ} \mathrm{C}$ indicated that an increase in the pretreatment time could promote the fiber sheet forming (Fig. 2. L1-L4).

However, a slightly brittle fiber sheet was observed under the steam explosion at $121^{\circ} \mathrm{C}$ for $120 \mathrm{~min}$. Comparing with alkaline pretreatment, the fiber sheets from WMB-L after boiling with $\mathrm{NaOH}$ at the concentration of $1.5 \% \mathrm{w} / \mathrm{w}$ for 120 min showed a better appearance including a smooth surface, light brown color, and increased toughness (Fig. 2. L8). Therefore, the effects of $\mathrm{NaOH}$ concentration were further investigated to optimize the fiber pretreatment of WMBL. From Fig. 2. (L9-L11), the increase of $\mathrm{NaOH}$ concentration at $5.5,9.5$, and $13.5 \% \mathrm{w} / \mathrm{w}$ promoted better fiber sheet forming, especially with $\mathrm{NaOH}$ at $13.5 \% \mathrm{w} / \mathrm{w}$ for $120 \mathrm{~min}$ (Fig. 2. L11). Using a high concentration of $\mathrm{NaOH}$ at a high temperature and long time could completely remove lignin and hemicellulose from the raw fiber. These results corresponded to previous reports, for example, increasing alkali concentration gave the proper properties of the physic nut (Jatropha curcas Linn.) pulps (15\% alkalinity) [33], and cornstalk paper $(20 \% \mathrm{NaOH})$ [34]. Accordingly, the fiber sheets prepared by alkaline pretreatment of WMB-L at 9.5 and $13.5 \% \mathrm{w} / \mathrm{w}$ of $\mathrm{NaOH}$ for $120 \mathrm{~min}$ were selected and analyzed for their physical properties including toughness, water absorption, swelling, and porosity, respectively.

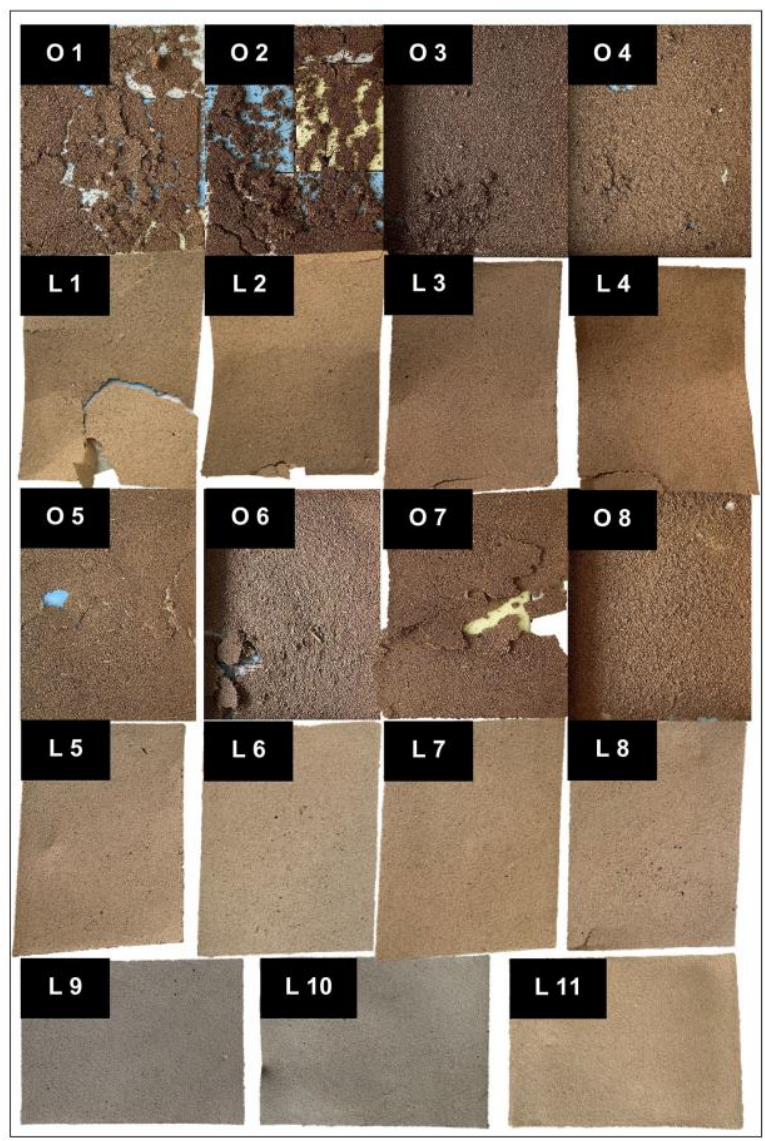

Fig. 2. Photographs of natural fiber sheets prepared from the waste mushroom bed of oyster mushroom (WMB-O) and lingzhi mushroom (WMB-L) with different pretreatment. O1O4: WMB-O with the steam explosion at $121^{\circ} \mathrm{C}$ for $5,60,90$, and $120 \mathrm{~min}$; L1-L4: WMB-L with the steam explosion at $121^{\circ} \mathrm{C}$ for $5,60,90$, and $120 \mathrm{~min}$; O5-O8: WMB-O with $\mathrm{NaOH}$ at $1.5 \% \mathrm{w} / \mathrm{w}$ for 5, 60, 90, and $120 \mathrm{~min}$; L5-L8: WMB$\mathrm{L}$ with $\mathrm{NaOH}$ at $1.5 \%$ w/w for 5, 60, 90, and 120 min; L9-L11: WMB-L with $\mathrm{NaOH}$ at 5.5, 9.5, and $13.5 \% \mathrm{w} / \mathrm{w}$ for $120 \mathrm{~min}$. 


\subsection{Toughness}

The toughness of the fiber sheet prepared by alkaline pretreatment of WMB-L at the concentration of 9.5 and $13.5 \% \mathrm{w} / \mathrm{w} \mathrm{NaOH}$ for $120 \mathrm{~min}$ was compared with the sheet of mulberry paper and printing paper (Fig. 3.). The results revealed that the fiber sheet from WMB-L pretreated with $\mathrm{NaOH}$ at 9.5 and $13.5 \% \mathrm{w} / \mathrm{w}$, could support the sand weight of $50.75 \pm 5.22$ and $76.47 \pm 18.35$ $\mathrm{g}$, respectively whereas, the printing paper and mulberry paper could support the sand weight of $1522.58 \pm 152.00$ and $1585.91 \pm 376.90 \mathrm{~g}$, respectively. These results presented that the fiber sheets from the pretreated WMB showed less toughness as compared with the commercial paper (the mulberry and printing paper). Due to the multi-step for commercial papermaking (i.e. pulp extraction, digestion, bleaching, paper formation), almost lignin and hemicellulose were removed from the raw materials [35]. The cellulose content of the mulberry paper and the printing paper from Eucalyptus has been reported as over $62-90 \%$ by oven dry weight $[9,36]$, which was higher than the WMB-L. This demonstrated that the higher cellulose content could promote the higher toughness of the paper. From this result, the tapioca starch was therefore applied as a natural binder to further improve the production of fiber sheets from the WMB.

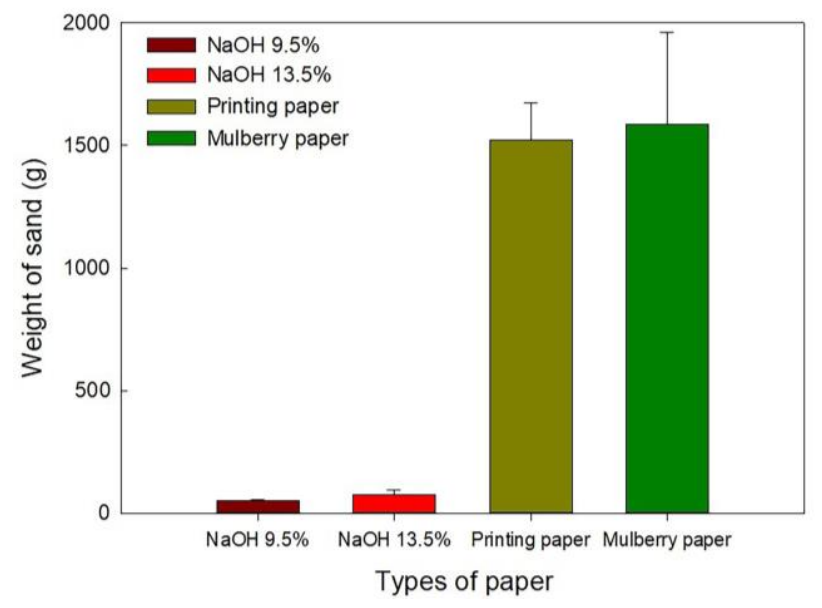

Fig. 3. Toughness of fiber sheet prepared from waste lingzhi mushroom bed after pretreatment with 9.5 and $13.5 \% \mathrm{w} / \mathrm{w}$ $\mathrm{NaOH}$ for 120 min, compared with the sheet of printing paper and mulberry paper.

\subsection{Water absorption and swelling}

The fiber sheet prepared from WMB-L pretreated with $\mathrm{NaOH}$ at 9.5 and $13.5 \% \mathrm{w} / \mathrm{w}$ showed the water absorption after water immersion for $30 \mathrm{~min}$ at $4.61 \pm 0.13$ and $5.14 \pm 0.14 \mathrm{~g} / \mathrm{g}$, respectively (Fig. 4.). Their water absorption was higher than that of the printing paper $(1.93 \pm 0.05 \mathrm{~g} / \mathrm{g})$, but lower than the mulberry paper $(7.99 \pm 0.15 \mathrm{~g} / \mathrm{g})$. The addition of $40 \mathrm{wt} \%$ of natural binder (i.e. tapioca starch) into the fiber sheet prepared from WMB-L treated with $\mathrm{NaOH}$ at $13.5 \%$ w/w could reduce its water absorption to $3.47 \pm 0.03 \mathrm{~g} / \mathrm{g}$. The water absorption of all samples was quite constant, even though the water immersion time increased. The results were corresponding with other reports that an increased amount of cellulose in the composite materials could improve water absorption due to the binding of the hydroxyl group in cellulose to the hydrogen bonds of water [37-40]. However, into the commercial process for printing paper production, surface strengthening, surface sizes or hydrophobic agents (e.g. starch) are usually added [41] to improve resistance level to the water absorption of water. Meanwhile, the printing paper needs a liquid holding capacity to quickly absorb and retain water or inks by micro capillarity [36].

The results of the swelling analysis are shown in Fig. 5. The printing paper showed the highest swelling of $42.76 \%$. Whereas the natural fiber sheet from the WMB-L with/without adding the natural binder and the mulberry paper showed contrary results, namely the compressed appearance and traces of decay due to water holding capacity after water immersion were observed (Fig. 6.). This phenomenon could be described that different raw materials and processes of pretreatment affected the structure of the fiber. The swellability depends upon the cell wall of the fiber, in other words, the higher microfibrils at the secondary wall of the fiber decrease swellability after water absorption but promote increasing strength [33-34, 14]. Moreover, the residual lignin after the pretreatment process, the addition of binder (such as starch), or introducing additives during the papermaking caused the different structure of the fiber, water absorption, and swelling properties [36-38].

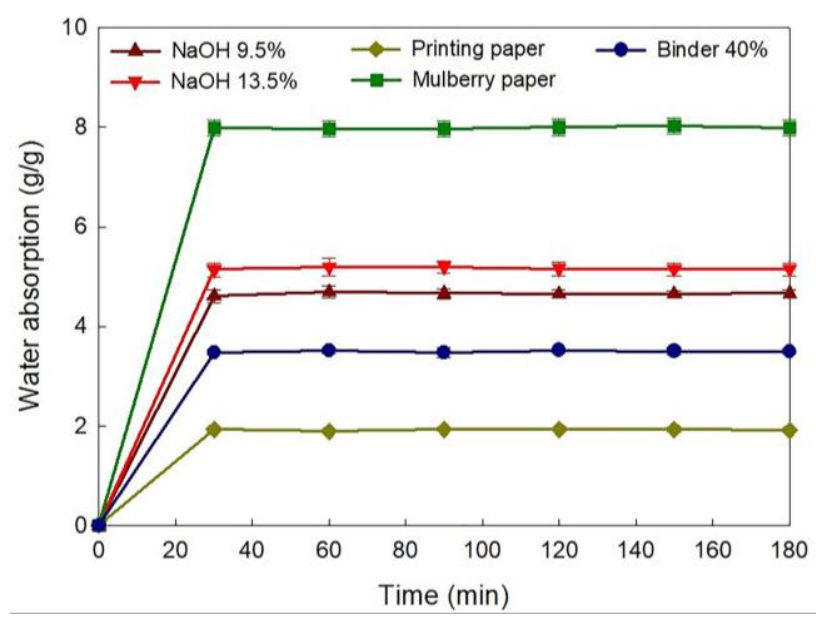

Fig. 4. Water absorption of fiber sheet prepared from waste lingzhi mushroom bed after pretreated with 9.5 and $13.5 \% \mathrm{w} / \mathrm{w}$ $\mathrm{NaOH}$ for $120 \mathrm{~min}$, and fiber sheet with $40 \mathrm{wt} \%$ binder compared with the sheet of printing paper and mulberry paper.

Although, good properties of the degradable cultivation vase from spent coffee grounds, shell lime, and rubberwood sawdust have ever been reported, their high water absorption and swelling, resulted in faster degradation (16 days) [10]. The strength of the cultivation vase is also one important property for production in the commercial. Moreover, the lifetime of the cultivation vase should be consistent with the growth time of cultivated plants, for example, the lingzhi and oyster mushroom require 75-90 days for their growth. Therefore, the optimal condition for fiber sheet forming 
to obtain the suitable properties for mushroom cultivation vase production is required for further investigation.

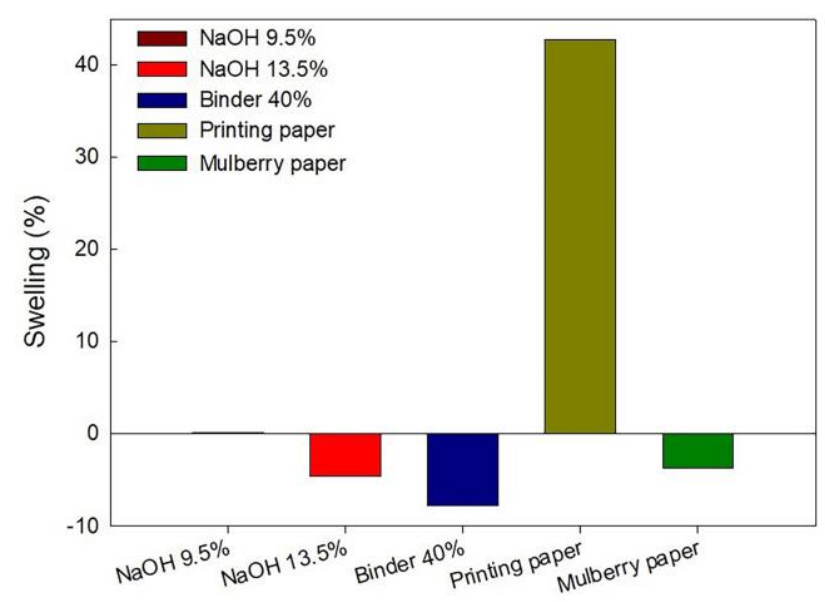

Types of paper

Fig. 5. Swelling of fiber sheet prepared from waste lingzhi mushroom bed after pretreated with 9.5 and $13.5 \% \mathrm{w} / \mathrm{w} \mathrm{NaOH}$ for $120 \mathrm{~min}$, and fiber sheet with $40 \mathrm{wt} \%$ binder compared with the sheet of printing paper and mulberry paper.

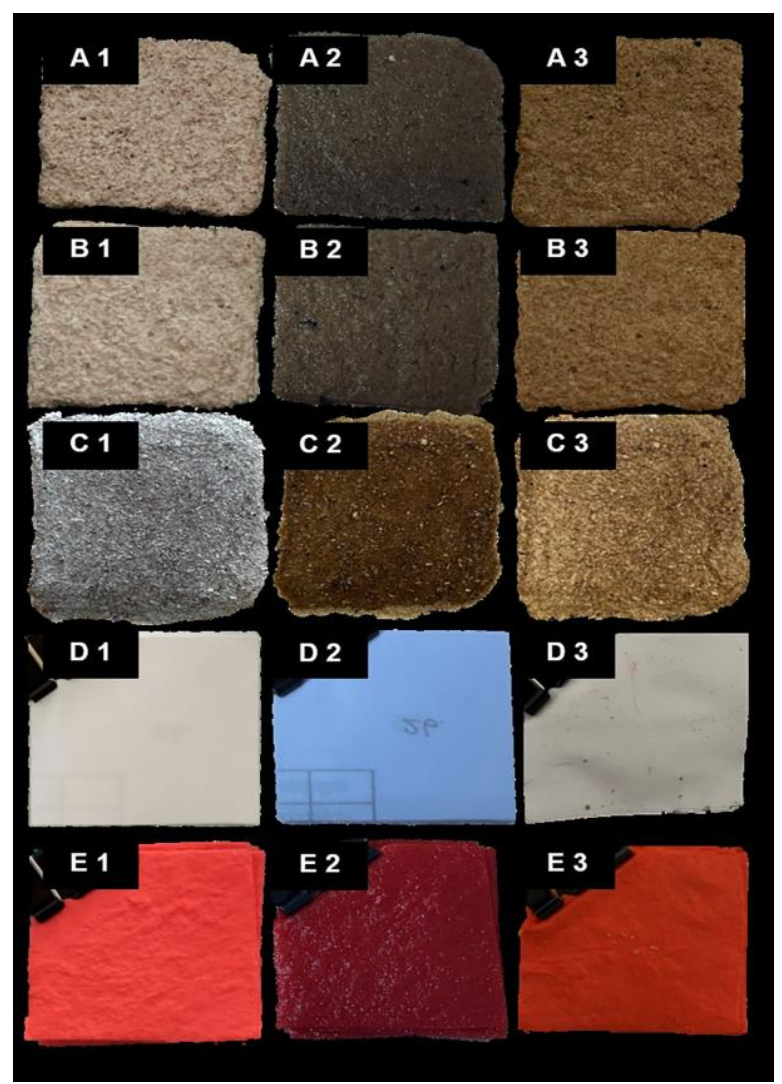

Fig. 6. Photographs of the fiber sheets prepared from waste lingzhi mushroom bed after pretreated with $9.5 \%$ w/w NaOH for $120 \mathrm{~min}(\mathrm{~A})$, and $13.5 \% \mathrm{w} / \mathrm{w} \mathrm{NaOH}(\mathrm{B})$; C) fiber sheet with $40 \mathrm{wt} \%$ binder; D) printing paper and; E) mulberry paper. The number of 1-3 mean the sample before soaking in water, after soaking in water and after soaking in water and left at room temperature for $16 \mathrm{~h}$, respectively.

\subsection{Porosity}

The porosity of the fiber sheet prepared by alkaline pretreatment of WMB-L with/without adding the natural binder, printing paper, and the mulberry paper are shown in Fig. 7. The porosity of the fiber sheet from the WMB$\mathrm{L}$ without binder was approximately $168-172 \%$ and slightly decreased in the fiber sheet with the binder, due to the increase of interaction between cellulose and binder (starch) [42-43]. Corresponding to the water absorption results in Fig. 4, the decrease of capacity of water uptake was found in the fiber sheet with the binder. This implied that the high porosity of fiber sheets could promote the increase of capacity to absorb and retain water in their structure [36]. While the printing paper and mulberry paper showed higher porosity than the fiber sheet with/without binder due to their higher cellulose contents $[9,36]$.

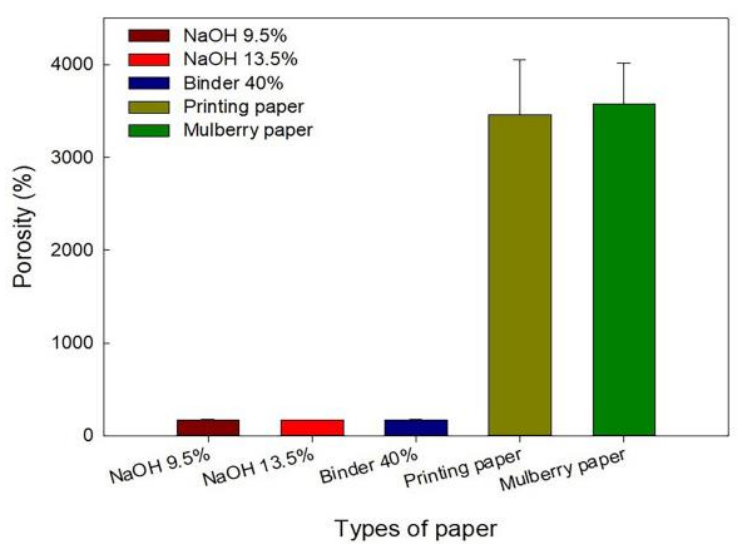

Fig. 7. The porosity of fiber sheet prepared from waste lingzhi mushroom bed after pretreated with 9.5 and $13.5 \%$ w/w NaOH for $120 \mathrm{~min}$, and fiber sheet with 40wt\% binder compared with the sheet of printing paper and mulberry paper.

From the results, the fiber sheet prepared from WMB-L demonstrated appropriate water absorption property and degradable behavior. This would be new alternative material for the possible production of valueadded materials, such as a water-absorbent and biodegradable fiber sheet for mushroom cultivation vase production. In addition, the use of WMB for preparing as alternative materials could promote zero waste in the mushroom farms. The summary of finding results and expected applications from this study are also compared with the other lignocellulosic materials, as shown in Table 2.

\section{Conclusions}

The WMB-O and WMB-L samples after harvesting for 7 days showed different chemical compositions due to the different use-life of each mushroom bed. The amount of $\alpha$-cellulose of the WMB were in the range of $27-35 \%$ dry basis, whereas, the lignin and hemicellulose were still high and might be the limitation of fiber sheet forming. The pretreatment processes by steam explosion 
and alkaline solution were optimized for the removal of lignin, hemicellulose, and other extractives. The fiber sheets derived from the alkaline pretreatment of the WMB-L at 9.5 and $13.5 \% \mathrm{w} / \mathrm{w}$ of $\mathrm{NaOH}$ for $120 \mathrm{~min}$ disclosed an opportunity for the production of valueadded materials, such as a water-absorbent and biodegradable fiber sheet for mushroom cultivation vase production. Natural binder, i.e. tapioca starch was added to improve the properties of the fiber sheet from the WMB-L. Although the finding results of fiber quantity/quality of the WMB-L have not yet qualified for papermaking as compared to commercial paper, such as mulberry paper and printing paper. Some physical properties results, such as water absorption, swelling, and porosity demonstrated the possibility for utilization in agricultural application. The high water absorption and traces of decay after water immersion of the fiber sheet from the WMB-L revealed a suitable water holding capacity for producing mushroom cultivation vase, and lead to zero waste in the mushroom farms. However, further study on the optimal condition for natural binder addition and the degradation behavior of the obtained fiber sheet from the WMB are required.

Table 2. Summary of the expected applications from several lignocellulosic materials.

\begin{tabular}{|c|c|c|c|}
\hline Material & Application & Characteristic & Reference \\
\hline Bamboo & $\begin{array}{l}\text { Carbonaceous } \\
\text { fiber sheets } \\
\text { for use as the } \\
\text { gas diffusion } \\
\text { layers }\end{array}$ & $\begin{array}{l}\text { - Fibrous } \\
\text { morphology } \\
\text { remained after } \\
\text { carbonization. } \\
\text { - Carbonaceous } \\
\text { fiber sheet was } \\
\text { able to electric } \\
\text { conductivity. }\end{array}$ & $\begin{array}{l}\text { Matsumura } \\
\text { et al. [13] }\end{array}$ \\
\hline $\begin{array}{l}\text { Banana } \\
\text { fiber }\end{array}$ & $\begin{array}{l}\text { Cellulose } \\
\text { nanofiber } \\
\text { for use as } \\
\text { reinforcing } \\
\text { elements }\end{array}$ & $\begin{array}{l}\text { - } \alpha \text {-cellulose } \\
\text { increased from } \\
64 \% \text { to } 95 \% \\
\text { after } \\
\text { pretreatment of } \\
\text { banana fiber. } \\
\text { - High aspect } \\
\text { ratio, } \\
\text { crystallinity, and } \\
\text { thermal stability }\end{array}$ & $\begin{array}{c}\text { Deepa } \\
\text { et al. [44] }\end{array}$ \\
\hline $\begin{array}{l}\text { WMB of } \\
\text { shiitake } \\
\text { (Lentinus } \\
\text { edodes) }\end{array}$ & $\begin{array}{c}\text { Cellulose } \\
\text { nanofiber } \\
\text { preparation }\end{array}$ & $\begin{array}{l}\text { - Cellulose } \\
\text { content of WMB } \\
\text { was } 25.4 \% \text {. } \\
\text { - Dry films of } \\
\text { cellulose } \\
\text { nanofiber } \\
\text { prepared from } \\
\text { WMB were } \\
\text { transparent. } \\
\end{array}$ & $\begin{array}{c}\text { Konno } \\
\text { et al. [45] }\end{array}$ \\
\hline $\begin{array}{c}\text { WMB of } \\
\text { lingzhi } \\
\text { (Ganoderma } \\
\text { lingzhi) }\end{array}$ & $\begin{array}{c}\text { Fiber sheets } \\
\text { preparation } \\
\text { for further } \\
\text { application in } \\
\text { mushroom } \\
\text { cultivation }\end{array}$ & $\begin{array}{l}\text { - } \alpha \text {-cellulose of } \\
\text { WMB was } \\
27.33 \% \text { dry } \\
\text { basis. } \\
\text { - Fiber sheet } \\
\text { from WMB } \\
\text { showed high } \\
\text { water absorption } \\
\text { and } \\
\text { biodegradability. }\end{array}$ & This study \\
\hline
\end{tabular}

\section{Acknowledgement}

Special thanks go to Thai Intellectual Learning Center (Samutprakarn province, Thailand) for their kind support and information, the National Research Council of Thailand through the NRCT Senior Research Scholar Program (Contract No. 814-2020) for the financial support.

\section{References}

1. P. Kalac, Mineral composition and radioactivity of edible mushrooms (Elsevier Inc., London, 2019)

2. M.C. Tseng, J.H. Luong, Mushroom cultivation technology for chemical production, Fermentation Processes, 7 (1984): 45-79

3. P. Karpilanondh, Mushroom technology (Textbook Publishing Center KMUTNB, 2018)

4. S. Ritnuch, Straw mushroom cultivation in a plastic bag (Offset Creation, 2009)

5. Z. Lou, Y. Sun, X. Zhou, S.A. Baig, B. Hu, X. Xu, Composition variability of spent mushroom substrates during continuous cultivation, composting process and their effects on mineral nitrogen transformation in soil, Geoderma Regional, 307, 19 (2017): 30-37

6. S. Wu, Y. Lan, Z. Wu, Y. Peng, S. Chen, Z. Huang, L. Xu, I. Gelbic, X. Guan, L. Zhang, S. Zou, Pretreatment of spent mushroom substrate for enhancing the conversion of fermentable sugar, Bioresource Technology, 148 (2013): 596-600

7. Z. Run-Hua, D. Zeng-Qiang, L. Zhi-Guo, Use of spent mushroom substrate as growing media for tomato and cucumber seedlings, Pedosphere, 22, 3 (2012): 333-342

8. H.N. lin, Y.T. Wang, M.J. Zhu, Evaluation of spent mushroom compost as a lignocellulosic substrate for hydrogen production by Clostridium thermocellum, International Journal of Hydrogen Energy, 42 (2017): 26687-26694

9. W. Anapanurak, B. Puangsin, Paper mulberry pulp properties by various alkaline processes, The research project for higher utilization of forestry and agricultural plant materials in Thailand (HUFA), (n.d.): $117-125$

10. W. ChaiChan, W. ChaiChan, A. Sawain, Plant pots from co-production of spent coffee grounds, shell lime and rubber wood sawdust (Rajamangala University of Technology Srivijaya, 2017)

11. Y.S. Cheng, P. Mutrakulcharoen, S. Chuetor, K. Cheenkachorn, P. Tantayotai, E.J. Panakkal, M. Sriariyanun, Recent situation and progress in biorefining process of lignocellulosic biomass: toward green economy, Applied Science and Engineering Progress, 13, 4 (2020): 299-311

12. B.D.S. Deeraj, K. Joseph, J.S. Jayan, A. Saritha, Dynamic mechanical performance of natural fiber reinforced composites: a brief review (Applied Science and Engineering Progress, 2021)

13. T. Matsumura, T. Kinumoto, M. Matsuoka, T. Tsumura, M. Toyoda, Preparation of carbonaceous 
fiber sheets derived from bamboo and application to gas diffusion layer of proton exchange membrane fuel cells (Oita University, 2015)

14. P. Kuntadong, M. Peekoh, O. Sindanjark, Biocomposite films based on cassava starch reinforced with durian rind cellulose fibers, RMUTP Research Journal, 13, 1 (2019): 39-50

15. H. Kargarzadeh, M. Loelovich, I. Ahmad, S. Thomas, A. Dufresne, Nanocellulose and cellulose nanocomposites (Wiley-VCH Verlag GmbH \& Co. KGaA - Weinheim, Germany, 2017)

16. C. Doree, The methods of cellulose chemistry including methods for the investigation of substances associated with cellulose in plant tissues (Chapman and Hall, London, 1947)

17. P. Teerapronchaisit, Polymers and biomolecules in organic compounds, (Department of Chemistry, Faculty of Applied Science, Khon Kaen University, 2010)

18. Y. Habibi, Key advances in the chemical modification of nanocelluloses, Chemical Society Reviews, 43 (2014): 151-1542

19. R.A. SHANKS, Natural fiber, composites materials, processes and applications, Woodhead Publishing Limited, (2014): 66-83

20. B. Boontima, A. Noomhorm, C. Puttanlek, D. Uttapap, V. Rungsardthong, Mechanical properties of sugarcane bagasse fiber-reinforced soy based biocomposites, Polymers and the Environment, 23, 1 (2014): 97-106

21. P. Saenghirunwattana, A. Noomhorm, V. Rungsardthong, Mechanical properties of soy protein based "green" composites reinforced with surface modified cornhusk fiber, Industrial Crops and Products, 60 (2014): 144-150

22. M.P. Arrieta, E. Fortunati, N. Burgos, M.A. Peltzer, J. López, L. Peponi, Nanocellulose-based polymeric blends for food packaging applications, multifunctional polymeric nanocomposites based on cellulosic reinforcements (Elsevier Inc., London, 2016)

23. R. Pawongrat, Pretreatment processes for enhancing the efficiency of ethanol production from lignocellulosic-agricultural wastes, Veridian EJournal, 2, 1 (2015): 143-157

24. S. Sriwongchai, Biodiesel production from agricultural wastes by using biotechnological process (Burapha University, 2017)

25. T. Piyang, W. Chaichan, K. Sagulsawasdipan, Environment-friendly plant pot production from palm oil sludge and mushroom cultured waste, RMUTSV Research Journal, 10, 3 (2018): 497-511

26. TAPPI's (Technical Association of the Pulp and Paper Industry) International Nanotechnology Division, Roadmap for the Development of International Standards for Nanocellulose, (2011)

27. N. Kongklom, C. Chuensangjun, Y. Chisti, S. Sirisansaneeyakul, Improved keeping quality of
Dendrobium "Bom" orchids using nutrients entrapped in a biodegradable hydrogel, Scientia Horticulturae, 234 (2018): 184-192

28. A. Atiqah, M. Jawaid, M.R. Ishak, S.M. Sapuan, Moisture absorption and thickness swelling behaviour of sugar palm fiber reinforced thermoplastic polyurethane, Procedia Engineering, 184 (2017): 581-586

29. P. Seephueak, C. Preecha, W. Seephueak, The study diversity of fungi and bacteria occurring on spent mushroom compost and utilization, Agricultural Technology, 13, 5 (2017)

30. S.H. Lim, Y.H. Lee, H.W. Kang, Efficient recovery of lignocellulolytic enzymes of spent mushroom compost from oyster mushroom, Pleurotus spp., and potential use in dye decolorization, Mycobiology, 41, 4 (2013): 214-220

31. J. Kumla, N. Suwannarach, K. Sujarit, W. Penkhrue, P. Kakumyan, K. Jatuwong, S. Vadthanarat, S. Lumyong, Cultivation of mushroom and their lignocellulolytic enzyme production through the utilization of agro-industrial waste, Molecules, 25, 12 (2020)

32. K.O. Reddy, C.U. Maheswari, M. Shukla, E. Muzenda, Preparation, chemical composition, characterization, and properties of Napier grass paper sheets, Separation Science and Technology, 49 (2014): 1527-1534

33. S. Butrat, Steam explosion for chemi-thermo mechanical pulping of physic nut (Jatropha curcas Linn.) for paper packaging applications, (Master of Science (Packaging Technology), (Department of Packaging and Materials Technology, Kasetsart University (n.d.))

34. Y. Fahmy, T.A. Fahmy, F. Mobarak, M.E. Sakhawy, M. Fadl, Agricultural residues (wastes) for manufacture of paper, board, and miscellaneous products: background overview and future prospects, ChemTech Research, Sphinx Knowledge House, 10, 2 (2017): 424-448

35. A. Guadie, A. Mulat, A. Kokeb, N. Gabbiye, Synthesis and characterization of Eucalyptus pulp by kraft process for paper sheet formation, Environmental Science and Technology, 1, 2 (2015): 20-26

36. V. Rana, G. Joshi, S.P. Singh, P.K. Gupta, Eucalypts in pulp and paper industry (Eucalypts, India, 2016)

37. M. Chaisupakitsin, W. Wongsirojanakul, A. Ruengkul, O. Siriwan, Acoustical panel from coconut coir / EPS hybrid composites, Science and Technology, 15, 2 (2007): 54-60

38. C. Homkhiew, S. Rawangwong, W. Boonchouytan, W. Thongruang, Mechanical and physical properties of thermoplastic natural rubber composites reinforced with rubberwood sawdust, SWU Engineering Journal, 13, 1 (2018): 107-122

39. C. Ngaowthong, V. Rungsardthong, S. Siengchin, Polypropylene/hemp woody core fiber composites: 
Morphology, mechanical, thermal properties, and water absorption behaviors, Mechanical Engineering, 8, 3 (2016): 1-10

40. V. Dogra, C. Kishore, A. Verma, A.K. Rana, A. Gaur, Fabrication and experimental testing of hybrid composite material having biodegradable bagasse fiber in a modified epoxy resin: evaluation of mechanical and morphological behavior (Applied Science and Engineering Progress, 2021)

41. J. Brander, Surface Application of paper chemicals (Chapman \& Hall, London, 1997)

42. I. Spiridon, C.A. Teaca, R. Bodirlau, M. Bercea, Behavior of cellulose reinforced cross-linked starch composite films made with tartaric acid modified starch microparticles, Polymers and the Environment, 21 (2013): 431-440
43. B. Nasri-Nasrabadi, M. Mehrasa, M. Rafienia, S. Bonakdar, T. Behzad, S. Gavanji, Porous starch/cellulose nanofibers composite prepared by salt leaching technique for tissue engineering, Carbohydrate Polymers, 108 (2014): 232-238

44. B. Deepa, E. Abraham, B.M. Cherian, A. Bismarck, J.J. Blaker, L.A. Pothan, A.L. Leao, S.F. Souza, M. Kottaisamy, Structure, morphology and thermal characteristics of banana nano fibers obtained by steam explosion, Bioresource Technology, 102 (2011): 1988-1997

45. N. Konno, M. Kimura, R. Okuzawa, Y. Nakamura, M. Ike, N. Hayashi, A. Obara, Y. Sakamoto, N. Habu, Preparation of cellulose nanofibers from waste mushroom bed of shiitak (Lentinus edodes) by TEMPO-mediated oxidation, Mokuzal Hozon (Wood Protection), 42 (2016): 157-164 